\title{
The Ross procedure is the optimal solution for young adults with unrepairable aortic valve disease
}

\author{
Ali Hage ${ }^{\#}$, Fadi Hage ${ }^{\#}$, Matthew Valdis, Linrui Guo, Michael W. A. Chu \\ Division of Cardiac Surgery, Department of Surgery, Western University, London Health Sciences Centre, London, ON, Canada \\ \#These authors contributed equally to this work. \\ Correspondence to: Dr. Michael W. A. Chu, MD, FRCSC. Professor of Surgery, B6-106 University Hospital, LHSC, 339 Windermere Road, London, \\ Ontario N6A 5A5, Canada. Email: michael.chu@lhsc.on.ca.
}

\begin{abstract}
While aortic valve repair remains the ideal intervention to restore normal valvular function, the optimal aortic valve substitute for patients with a non-repairable aortic valve remains an ongoing subject for debate. In particular, younger patients with a non-repairable valve represent a unique challenge because of their active lifestyle and long life expectancy, which carries a higher cumulative risk of prosthesis-related complications. The Ross procedure, unlike prosthetic or homograft aortic valve replacement (AVR), provides an expected survival equivalent to that of the age and gender-matched general population. Contemporary data has shown that the Ross procedure can be performed safely in centers with expertise, and is associated with improved valvular durability, hemodynamics and quality of life.
\end{abstract}

Keywords: Ross procedure; adults; aortic valve disease

Submitted Jan 30, 2021. Accepted for publication May 05, 2021.

doi: 10.21037/acs-2021-rp-26

View this article at: http://dx.doi.org/10.21037/acs-2021-rp-26

\section{Introduction}

The optimal aortic valve substitute in young adults remains controversial. Aortic valve repair remains the best primary intervention to restore normal valvular function and circumvent early and late complications related to valve replacement. However, a large patient population does not exhibit favorable anatomical characteristics that would allow for an effective and durable repair, necessitating an aortic valve replacement (AVR) (1). The ideal aortic valve substitute would provide excellent hemodynamics, low thrombogenicity, low risk of prothesis dysfunction or endocarditis and good long-term durability. Currently available valve replacement options include conventional mechanical or biological prostheses, rapid deployment prostheses, stentless biological prostheses, aortic homografts and pulmonary autografts (Ross procedure). Although standard mechanical or biological prostheses remain the most common choice selected across most age groups, young adults represent a unique group of patients because of their anticipated long life expectancy and thus higher cumulative risk of prosthesis-related complications. The Ross procedure, unlike conventional bioprosthetic or mechanical AVR, provides an expected survival equivalent to that of the age and gender-matched general population by minimizing prosthesis-related complications, avoidance of anticoagulation, and superior hemodynamics $(2,3)$.

\section{Background}

The Ross procedure was first described more than sixty years ago by Lower and colleagues when an excised pulmonic valve was implanted in the descending aorta in a canine model (4). Less than a decade later, Ross and colleagues described the use of the living pulmonary autograft in the aortic position with the hope that it would overcome the late degeneration of the aortic homografts (5). Since the first report in 1967 , the popularity of the Ross procedure has fluctuated over time, but more recently has nearly disappeared from the armamentarium of most cardiac surgery centers. In the last decade, the Ross procedure has constituted less than $0.1 \%$ of all AVRs performed in the 
United States (6). Despite that, a small group of centers have continued to perform and refine the procedure and have provided long-term reports that support the superiority of the Ross procedure over other AVR options for selected adults with aortic valve disease (7-13).

\section{Survival}

As previously mentioned, conventional AVR has long been considered the mainstay therapy in adults with nonrepairable aortic valve disease, with younger adults (less than fifty years of age) preferentially receiving mechanical valves and those over the age of seventy receiving bioprostheses (14). Several contemporary studies have suggested this approach to be outdated and especially at odds with the available body of evidence supporting the imperative role of the Ross procedure in younger adults (7-12). In fact, when implanted in young and middle-aged adults, both bioprosthetic and mechanical valves are associated with excess mortality, which appears to be inversely proportional to patient age at the time of surgery (15-18). The majority of recent studies examining long-term outcomes following AVR have shown that the Ross procedure is the only operation capable of restoring expected survival equivalent to that of the age and gender-matched general population $(2,3)$. Whereas no study has shown similar results following AVR with conventional prostheses or aortic homografts, even in highly selected patient series $(7,16)$. Moreover, when performed in centers of excellence, the Ross procedure carries a risk of perioperative mortality and major morbidity that is similar to mechanical AVR (19). The superior longterm survival conferred by the Ross procedure in younger adults is believed to be the result of reduced prosthesisrelated complications, absence of anticoagulation and superior hemodynamics attributable to a living aortic valve substitute. The survival advantage with the Ross operation has been demonstrated repeatedly in several single and multi-center cohort series $(8-12,17,20-25)$, meta-analyses $(18,26,27)$ and a randomized controlled trial $(7)$.

\section{Valve-related complications}

The Ross procedure, despite its technical complexity and steep learning curve, provides an opportunity to reduce valve-related complications as compared to conventional AVR. In young adults, bioprostheses (stented or stentless) are associated with excess rates of structural valve deterioration requiring reoperation $(28,29)$. This limited durability is further accentuated by the presence of patient-prosthesis mismatch, which can be seen in up to $25 \%$ of patients with stented prostheses (30-32). With the expanding indications of transcatheter AVR and valve-invalve options, there has been a steady increase in the use of bioprostheses for AVR over the last twenty years. However the majority of implanted bioprosthesis have an aortic annulus of 21 and $23 \mathrm{~mm}$, both of which can potentially result in suboptimal hemodynamics with the currently available valve-in-valve technologies (33). Additionally, serial valve-in-valve strategies, which would undoubtedly be necessary in young patients undergoing a tissue AVR, are prone to exponentially increasing transvalvular gradients and reduced durability with each successive valve-in-valve intervention, prompting re-operation due to serial-valve failure.

In young adults, several randomized and observational studies have demonstrated superior outcomes with the use of mechanical valves versus bioprosthetic valves (34-36). However, the use of mechanical prostheses brings forward the challenges of thromboembolism, valve thrombosis and bleeding events secondary to anticoagulation. In fact, it is estimated that one-half of patients with mechanical AVR aged twenty-five years, and one-third of those aged fiftyfive years will experience a thrombotic or bleeding event during their lifetime (37). Even in a highly regulated and closely monitored FDA trial, annual risks of bleeding and thromboembolism following mechanical AVR exceeded 5\% per patient year (38).

In contrast, the current literature reports lower incidences of thromboembolism, bleeding and valve-related events with the Ross procedure. One major hindrance to the widespread use of the Ross procedure stems from concerns regarding the adaptability of the pulmonary autograft to its new aortic position. Some early studies postulated that long-term exposure to systemic pressures could lead to progressive autograft dilatation in some patients and consequently a potentially higher rate of reintervention (39-43). Since then, the growing body of evidence has shown this to be true, especially amongst patients undergoing the Ross procedure specifically for aortic regurgitation (AR). Patients with significant AR were found to be more prone to autograft dilatation and reintervention than those with isolated aortic stenosis (AS) $(44,45)$. Recent studies attribute these earlier findings to incomplete stabilization of the aortic root at the index surgery, resulting in autograft dilatation at the level of the annulus, sinuses of Valsalva and sinotubular junction (46-49). When a tailored 
approach is employed in a high-volume center to ensure adequate support of the pulmonary autograft, the Ross procedure results in excellent autograft durability (50). On the other hand, the pulmonary homograft, when implanted into the low-pressure pulmonary circulation, is expected to be less vulnerable to structural degeneration (51). However, the durability of the pulmonary homograft remains the Achilles heel of the Ross procedure. Fortunately, reoperation for pulmonary homograft failure remains low at approximately $1 \%$ per year and transcatheter techniques have helped to mitigate the impact when needed.

The choice of AVR procedure in aortic infective endocarditis presents its own set of challenges. This is in part due to the risk of recurrent infection of the prosthetic valve which despite being low, still remains an important consideration. In young adults, this is further compounded by the risk of reoperation, implication to lifestyle and the need for anticoagulation in the case of mechanical valves. A recent multicenter study found that in selected patients with infective endocarditis, the Ross procedure was a safe and reasonable alternative to AVR with good mid-term outcomes and excellent freedom from recurrent infection, supporting the potential role of the living autograft in this challenging patient population (52).

\section{Hemodynamics}

The aortic root is a dynamic, physiologic structure that allows adaptive blood flow to both the systemic and coronary circulation. Various studies have demonstrated that the aortic root is not simply "three cusps in a pipe", but that in fact the four structures that make up the aortic root (aortic annulus, cusps, sinuses and sinotubular junction) are highly dynamic and act dependently in response to systolic and diastolic forces (53). Impairment of at least one of these structures is believed to impact the overall function of the aortic root and results in sub-optimal systemic and coronary perfusion. Biological and mechanical prostheses consist of a fixed inflow ring, which effectively fixes the aortic annulus and impairs the dynamic function of the aortic root. As for the Ross procedure, the pulmonary autograft is a living structure that allows for remodeling and adaptive hemodynamic performance. In fact, the pulmonary autograft is associated with significantly lower and nearphysiologic transvalvular gradients at discharge and followup versus conventional AVR (54). When compared with aortic homografts, both the pulmonary autograft (i.e.,
Ross procedure) and the homograft have excellent early hemodynamics; however, only the pulmonary autograft maintains consistently low transvalvular gradients at long-term follow-up $(7,55)$. Pulmonary autografts are vascularized, highly viable and immunoprivileged living tissues, whereas homografts are cryopreserved, partially viable and less biologically active (52,54-56). This superior hemodynamic profile has been demonstrated with transaortic blood flow patterns analyzed by magnetic resonance imaging (57). The hemodynamic advantages of the pulmonary autograft can be seen under resting conditions, but the difference with other valve substitutes is further accentuated during periods of exertion. In fact, several studies have demonstrated that gradients across the pulmonary autograft do not significantly increase with maximal exercise, which closely emulates the hemodynamic performance of native aortic valves in healthy individuals, as opposed to the significantly increased gradients expected with exercise in normally functioning prosthetic AVR $(20,55,58,59)$. Hence, the pulmonary autograft should be given strong consideration as the valve of choice in younger, physically active patients because of their increased hemodynamic demands and the optimal near-physiologic performance of the pulmonary autograft. Additionally, the favorable hemodynamics of the pulmonary autograft may contribute to more rapid and complete left ventricular mass regression and reduced congestive heart failure, which is believed to be a driving force behind the improvement in mortality and quality of life $(60,61)$.

\section{Quality of life}

Another important advantage of the Ross procedure in young adults is the improvement in the quality of life compared to conventional AVR. The Ross procedure was shown to rank higher on both the physical and psychological health scales (62-64). Importantly, the Ross procedure obliviates the need for anticoagulation incumbent with mechanical valves, which constitutes an important consideration in this patient population where individuals are more physically active and where anticoagulation is sometimes not practical or better avoided, such as in women of childbearing age contemplating pregnancy (65). The impact of warfarin dosing and international normalized ratio (INR) management should not be underestimated particularly in this active, mobile population, as it requires a significant commitment and change in quality of life. 


\section{Tailored approach}

To mitigate the risk of potential early changes in autograft root dimensions following exposure to systemic pressures and the consequent autograft failure, several groups advocate for the institution of an individualized, tailored approach $(50,66)$. Patients undergoing the Ross procedure for aortic insufficiency and those with a dilated aortic annulus greater than or equal to $27 \mathrm{~mm}$ preoperatively are particularly prone to this complication (66). Reducing the size of the aortic annulus with suture plication was proposed as a safeguard measure to prevent early dilatation; however, this technique was not shown to prevent late failure based on the available long-term data (66). Extraaortic annuloplasty has recently been added to the cardiac surgeon's toolbox and has shown promising results in reducing the risk of later aortic annular dilatation (67-69). This technique is currently used at our center as well as at other institutions. However, longer follow-up is needed to support its effectiveness in stabilizing the aortic annulus of Ross procedure patients. A study by Hokken et al. reinforced the predictive role of early autograft annular stabilization on late outcomes and showed that most of the increase in aortic diameter was already reached at the time of discharge from the hospital (43). Based on similar principles, it is important to stabilize the sinotubular junction when the ascending aorta measures greater than $35-40 \mathrm{~mm}$ in diameter.

Thus, the ideal candidate for the Ross procedure is a patient with a projected life expectancy of more than fifteen years, who presents with aortic valve disease (ideally isolated AS), a nondilated aortic annulus (less than $27 \mathrm{~mm}$ ) and normal aortic dimensions $(44,45,50,66,70)$ The Ross procedure should also be given particular consideration in female patients of childbearing age contemplating pregnancy, patients with a high level of physical activity and those who have contraindications to or prefer to avoid anticoagulation. Conventional AVR is not well suited to women contemplating a future pregnancy given the major setbacks of both bioprosthetic and mechanical prostheses. Mechanical valves are associated with an accrued risk of thrombosis during pregnancy and the currently available options for anticoagulation carry a safety concern to both the mother and fetus $(65,71)$. The bioprostheses on the other hand may have limited durability with accelerated degeneration during pregnancy, which could in fact be related to the younger age of the patient $(72,73)$. The Ross procedure is contraindicated in patients with connective tissue disorders or familial aortopathy, due to a prohibitive risk of autograft dilatation and failure, and relatively contraindicated in some autoimmune diseases (such as lupus erythematosus and rheumatoid arthritis) because of concerns of acquired cusp disease (74).

\section{Other technical tips and tricks}

Several technical refinements have been proposed at each step of the operation to improve its performance and durability (46-48,50,75,76). At our institution, we routinely try to preserve as much native aortic wall as possible, such as the non-coronary sinus and the bridge of aortic wall between the left/right sinus (Figure $1 A$ ), which we later incorporate into the anastomosis with the ascending aorta to provide external support for the pulmonary autograft (Figure $1 B$ ). During autograft harvesting, the pulmonary autograft is trimmed at its base to eliminate any excess muscle (within 2-3 mm below the cusp insertion line) and the base of the autograft is tailored to the shape of the native aortic annulus, whether tricuspid, bicuspid or unicuspid. We prefer to implant the autograft deep within the left ventricular outflow tract to stabilize the annulus using a full-root technique to avoid any mismatch between the aortic and pulmonary roots, which often exhibit different dimensions and commissural orientations (Figure 2). We believe that the single interrupted suturing technique allows more accurate suture placement and allows us to implant the pulmonary autograft symmetrically within the left ventricular outflow tract, which we believe is important for valvular competence. As mentioned, we routinely perform an external aortic annuloplasty using a ring of Dacron graft for annular diameters of $27 \mathrm{~mm}$ or greater on preoperative imaging or in patients presenting with significant AR or mixed AS/aortic insufficiency to prevent late dilatation (Figure 3). This is carried out with a Dacron aortic ring using a subannular row of six non-pledgeted 2-0 Ethibond sutures. We usually implant the pulmonary homograft prior to anastomosing the distal end of the autograft to facilitate distal homograft reconstruction at the pulmonary bifurcation. During the distal aortic anastomosis of the pulmonary autograft, the distal end of the autograft is kept as short as possible by leaving only $2 \mathrm{~mm}$ above the commissural insertion level to minimize the amount of pulmonary autograft tissue exposed to systemic pressures. When the ascending aorta is dilated greater than $35-40 \mathrm{~mm}$, we routinely replace a short segment of the ascending aorta with a 24 or $26 \mathrm{~mm}$ Dacron graft to avoid distracting the sinotubular junction of the pulmonary autograft in order to 

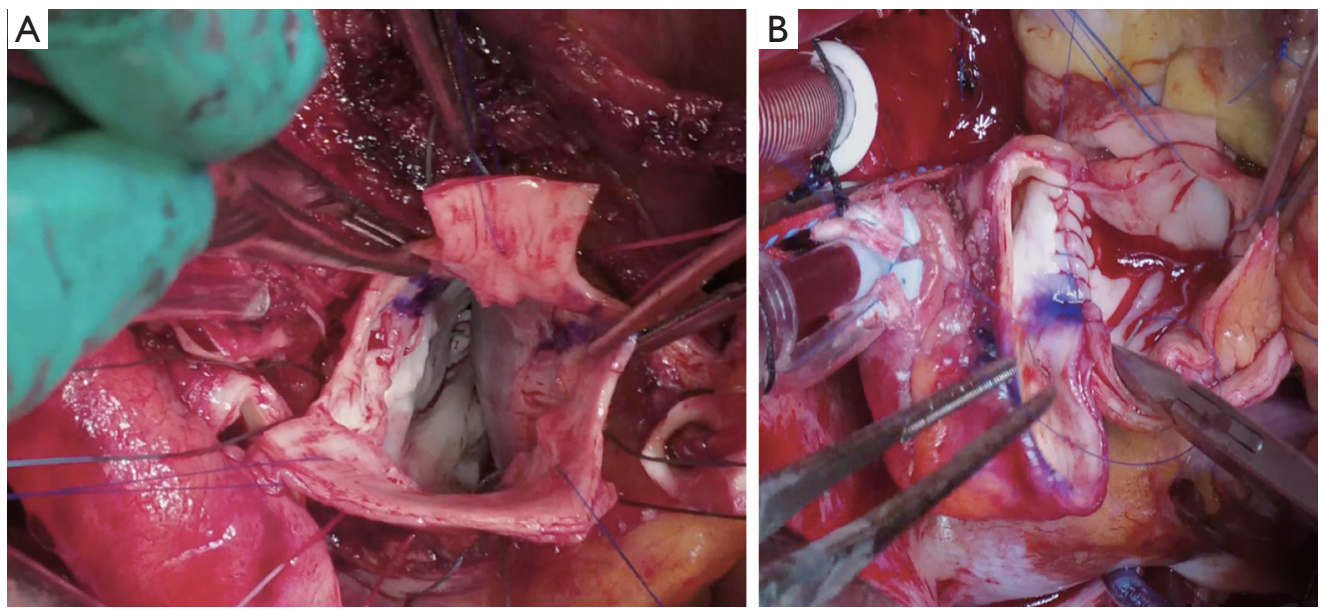

Figure 1 Preservation of non-coronary sinus and bridge of aortic wall between the left/right sinus (A) to be later incorporated into the anastomosis with the ascending aorta for further pulmonary autograft external support (B).

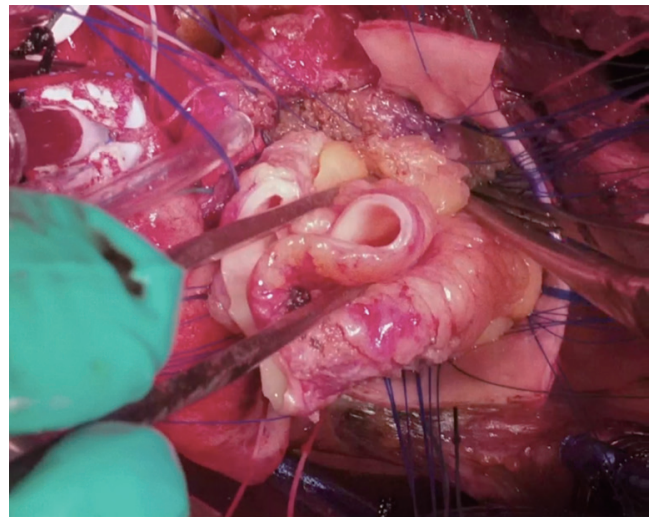

Figure 2 Multiple interrupted 5-0 polypropylene sutures for proper pulmonary autograft implantation into the LVOT and exclusion of infundibular muscle. LVOT, left ventricular outflow tract.

optimize valve function and durability.

In the post-operative period, it is crucial to avoid elevated systemic pressures which may lead to early dilatation of the pulmonary autograft, and to allow the neoaortic root to adapt to its new hemodynamic environment. This is based on previous biomechanical studies showing that physiological adaptation of the autograft is only possible when the wall stress is kept in the lower range of the strainstress curve, and is generally achieved by aiming for a systolic blood pressure of less than 100 to $110 \mathrm{mmHg}$, particularly during the first six to twelve months (adaptive period) following the operation (77).

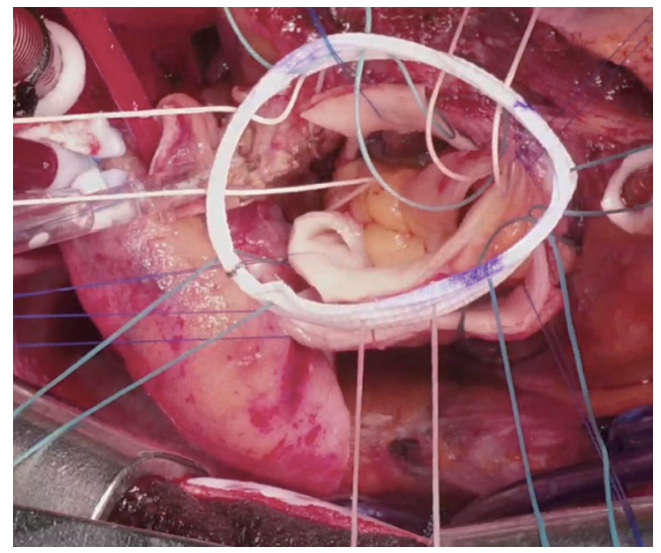

Figure 3 External aortic annuloplasty for annular diameters of $27 \mathrm{~mm}$ or greater on preoperative imaging or in patients presenting with significant aortic regurgitation or mixed AS/AI to prevent late dilatation. AS, aortic stenosis; AI, aortic insufficiency.

\section{Guidelines}

Despite the convergence of studies supporting its safety and effectiveness, the Ross procedure has not yet gained widespread acceptance and the most recent guidelines do not yet reflect its important role in treating aortic valve disease, particularly in young adults. The latest American guidelines give the Ross procedure a class IIb recommendation in young patients, whereas both bioprosthetic and mechanical prostheses were given class 1 and 2 a recommendations respectively, with several considerations (14). Oddly, the most recent European 
guidelines do not even mention the Ross procedure $(78,79)$. It is difficult to reconcile these guideline recommendations in the face of the published cohort, meta-analyses and randomized evidence supporting the advantages of the Ross procedure over conventional AVR options, particularly when performed in centers of expertise. Skeptics of the Ross procedure have argued that most published studies on its outcomes originate from specialized high-volume centers, which limits the external validity of this body of data (7-12,17,18,20-27,80). However, this argument also applies to other highly specialized procedures such as complex valve repair, aortic arch or thoracoabdominal aortic repair and transcatheter valve interventions, which appear to have gained much broader appeal and guideline support than the Ross procedure. Strong consideration should be made to re-evaluate AVR guidelines to reflect the increasing body of evidence supporting the Ross procedure in young patients.

\section{Conclusions}

Selecting the most appropriate valve substitute for nonrepairable aortic valves is a difficult task, particularly for younger patients. Interest in the Ross procedure has recently seen a revival as a growing body of evidence has demonstrated its superior outcomes in adults compared to conventional AVR options. The Ross procedure provides excellent long-term survival, freedom from valve-related complications and improved quality of life in selected patients when the procedure is performed in experienced centers. With this resurgence, refinements to the procedure have been made to extend its durability, in particular by stabilizing the aortic annulus. Accordingly, there is a dire need to revisit the current guidelines to reflect the contemporary evidence supporting the pulmonary autograft, rather than the perceived biases thrust upon it.

\section{Acknowledgments}

Funding: None.

\section{Footnote}

Conflicts of Interest: MWAC has received speaker's honorarium from Medtronic, Edwards Lifesciences, Terumo Aortic, Abbott Vascular and Boston Scientific. The other authors have no conflicts of interest to declare.

Open Access Statement: This is an Open Access article distributed in accordance with the Creative Commons Attribution-NonCommercial-NoDerivs 4.0 International License (CC BY-NC-ND 4.0), which permits the noncommercial replication and distribution of the article with the strict proviso that no changes or edits are made and the original work is properly cited (including links to both the formal publication through the relevant DOI and the license). See: https://creativecommons.org/licenses/by-nc-nd/4.0/.

\section{References}

1. David TE. Aortic valve repair and aortic valve-sparing operations. J Thorac Cardiovasc Surg 2015;149:9-11.

2. Mazine A, El-Hamamsy I, Verma S, et al. Ross Procedure in Adults for Cardiologists and Cardiac Surgeons: JACC State-of-the-Art Review. J Am Coll Cardiol 2018;72:2761-77.

3. Sibilio S, Koziarz A, Belley-Côté EP, et al. Outcomes after Ross procedure in adult patients: A meta-analysis and microsimulation. J Card Surg 2019;34:285-92.

4. Lower RR, Stofer RC, Shumway NE. Autotransplantation of the pulmonic valve into the aorta. J Thorac Cardiovasc Surg 1960;39:680-7.

5. Ross DN. Replacement of aortic and mitral valves with a pulmonary autograft. Lancet 1967;2:956-8.

6. Reece TB, Welke KF, O'Brien S, et al. Rethinking the ross procedure in adults. Ann Thorac Surg 2014;97:175-81.

7. El-Hamamsy I, Eryigit Z, Stevens LM, et al. Longterm outcomes after autograft versus homograft aortic root replacement in adults with aortic valve disease: a randomised controlled trial. Lancet 2010;376:524-31.

8. David TE, David C, Woo A, et al. The Ross procedure: outcomes at 20 years. J Thorac Cardiovasc Surg 2014;147:85-93.

9. Skillington PD, Mokhles MM, Takkenberg JJM, et al. The Ross procedure using autologous support of the pulmonary autograft: techniques and late results. J Thorac Cardiovasc Surg 2015;149:S46-52.

10. Mastrobuoni S, de Kerchove L, Solari S, et al. The Ross procedure in young adults: over 20 years of experience in our Institution. Eur J Cardiothorac Surg 2016;49:507-12; discussion 512-3.

11. Martin E, Mohammadi S, Jacques F, et al. Clinical Outcomes Following the Ross Procedure in Adults: A 25-Year Longitudinal Study. J Am Coll Cardiol 2017;70:1890-9.

12. Sievers HH, Stierle U, Charitos EI, et al. A multicentre evaluation of the autograft procedure for young 
patients undergoing aortic valve replacement: update on the German Ross Registry. Eur J Cardiothorac Surg 2016;49:212-8.

13. Sievers HH, Stierle U, Charitos EI, et al. Major Adverse Cardiac and Cerebrovascular Events After the Ross Procedure: A Report From the German-Dutch Ross Registry. Circulation 2010;122:S216-23.

14. Otto CM, Nishimura RA, Bonow RO, et al. 2020 ACC/ AHA Guideline for the Management of Patients With Valvular Heart Disease: A Report of the American College of Cardiology/American Heart Association Joint Committee on Clinical Practice Guidelines. Circulation 2021;143:e72-e227.

15. Bourguignon T, Bouquiaux-Stablo AL, Candolfi P, et al. Very long-term outcomes of the Carpentier-Edwards Perimount valve in aortic position. Ann Thorac Surg 2015;99:831-7.

16. Bouhout I, Stevens LM, Mazine A, et al. Long-term outcomes after elective isolated mechanical aortic valve replacement in young adults. J Thorac Cardiovasc Surg 2014;148:1341-1346.e1.

17. Mazine A, David TE, Rao V, et al. Long-Term Outcomes of the Ross Procedure Versus Mechanical Aortic Valve Replacement: Propensity-Matched Cohort Study. Circulation 2016;134:576-85.

18. Mazine A, Rocha RV, El-Hamamsy I, et al. Ross Procedure vs Mechanical Aortic Valve Replacement in Adults: A Systematic Review and Meta-analysis. JAMA Cardiol 2018;3:978-87.

19. Bouhout I, Noly PE, Ghoneim A, et al. Is the Ross procedure a riskier operation? Perioperative outcome comparison with mechanical aortic valve replacement in a propensity-matched cohort. Interact Cardiovasc Thorac Surg 2017;24:41-7.

20. da Costa F, Haggi H, Pinton R, et al. Rest and exercise hemodynamics after the Ross procedure: an echocardiographic study. J Card Surg 1998;13:177-85.

21. Andreas M, Seebacher G, Reida E, et al. A single-center experience with the ross procedure over 20 years. Ann Thorac Surg 2014;97:182-8.

22. Sievers HH, Stierle U, Petersen $M$, et al. Valve performance classification in 630 subcoronary Ross patients over 22 years. J Thorac Cardiovasc Surg 2018;156:79-86.e2.

23. Yacoub MH, Klieverik LMA, Melina G, et al. An evaluation of the Ross operation in adults. J Heart Valve Dis 2006;15:531-9.

24. Buratto E, Shi WY, Wynne R, et al. Improved Survival
After the Ross Procedure Compared With Mechanical Aortic Valve Replacement. J Am Coll Cardiol 2018;71:1337-44.

25. Sharabiani MTA, Dorobantu DM, Mahani AS, et al. Aortic Valve Replacement and the Ross Operation in Children and Young Adults. J Am Coll Cardiol 2016;67:2858-70.

26. McClure GR, Belley-Cote EP, Um K, et al. The Ross procedure versus prosthetic and homograft aortic valve replacement: a systematic review and meta-analysis. Eur J Cardiothorac Surg 2019;55:247-55.

27. Etnel JRG, Grashuis P, Huygens SA, et al. The Ross Procedure: A Systematic Review, Meta-Analysis, and Microsimulation. Circ Cardiovasc Qual Outcomes 2018;11:e004748.

28. Forcillo J, El Hamamsy I, Stevens LM, et al. The perimount valve in the aortic position: twenty-year experience with patients under 60 years old. Ann Thorac Surg 2014;97:1526-32.

29. Une D, Ruel M, David TE. Twenty-year durability of the aortic Hancock II bioprosthesis in young patients: is it durable enough? Eur J Cardiothorac Surg 2014;46:825-30.

30. Botzenhardt F, Eichinger WB, Guenzinger R, et al. Hemodynamic performance and incidence of patientprosthesis mismatch of the complete supraannular perimount magna bioprosthesis in the aortic position. Thorac Cardiovasc Surg 2005;53:226-30.

31. Pibarot P, Dumesnil JG. Prosthesis-patient mismatch: definition, clinical impact, and prevention. Heart 2006;92:1022-9.

32. Deutsch MA, Prinzing A, Fiegl K, et al. Early haemodynamic performance of a latest generation supra-annular aortic bioprosthesis: experience from a large single-centre series. Eur J Cardiothorac Surg 2016;49:1691-8.

33. El-Hamamsy I, Bouhout I. The Ross procedure: time for a hard look at current practices and a reexamination of the guidelines. Ann Transl Med 2017;5:142.

34. Goldstone AB, Chiu P, Baiocchi M, et al. Mechanical or Biologic Prostheses for Aortic-Valve and Mitral-Valve Replacement. New Engl J Med 2017;377:1847-57.

35. Weber A, Noureddine H, Englberger L, et al. Ten-year comparison of pericardial tissue valves versus mechanical prostheses for aortic valve replacement in patients younger than 60 years of age. J Thorac Cardiovasc Surg 2012;144:1075-83.

36. Stassano P, Di Tommaso L, Monaco M, et al. Aortic valve replacement: a prospective randomized evaluation of mechanical versus biological valves in patients ages 55 to 
70 years. J Am Coll Cardiol 2009;54:1862-8.

37. Korteland NM, Etnel JRG, Arabkhani B, et al. Mechanical aortic valve replacement in non-elderly adults: metaanalysis and microsimulation. Eur Heart J 2017;38:3370-7.

38. Puskas J, Gerdisch M, Nichols D, et al. Reduced anticoagulation after mechanical aortic valve replacement: interim results from the prospective randomized on-X valve anticoagulation clinical trial randomized Food and Drug Administration investigational device exemption trial. J Thorac Cardiovasc Surg 2014;147:1202-10; discussion 1210-1.

39. Mookhoek A, Krishnan K, Chitsaz S, et al. Biomechanics of Failed Pulmonary Autografts Compared to Native Aortic Roots. Ann Thorac Surg 2017;103:1482-8.

40. Luciani GB, Casali G, Favaro A, et al. Fate of the aortic root late after Ross operation. Circulation 2003;108 Suppl 1:II61-67.

41. Simon-Kupilik N, Bialy J, Moidl R, et al. Dilatation of the autograft root after the Ross operation. Eur J Cardiothorac Surg 2002;21:470-3.

42. Kouchoukos NT, Masetti P, Nickerson NJ, et al. The Ross procedure: long-term clinical and echocardiographic follow-up. Ann Thorac Surg 2004;78:773-81; discussion 773-81.

43. Hokken RB, Takkenberg JJM, van Herwerden LA, et al. Excessive pulmonary autograft dilatation causes important aortic regurgitation. Heart 2003;89:933-4.

44. Ryan WH, Prince SL, Culica D, et al. The Ross procedure performed for aortic insufficiency is associated with increased autograft reoperation. Ann Thorac Surg 2011;91:64-9; discussion 69-70.

45. David TE, Ouzounian M, David CM, et al. Late results of the Ross procedure. J Thorac Cardiovasc Surg 2019;157:201-8.

46. Juthier F, Banfi C, Vincentelli A, et al. Modified Ross operation with reinforcement of the pulmonary autograft: Six-year results. J Thorac Cardiovasc Surg 2010;139:1420-3.

47. Ungerleider RM, Ootaki Y, Shen I, et al. Modified Ross procedure to prevent autograft dilatation. Ann Thorac Surg 2010;90:1035-7; discussion 1037.

48. Carrel T, Kadner A. Long-Term Clinical and Imaging Follow-Up After Reinforced Pulmonary Autograft Ross Procedure. Semin Thorac Cardiovasc Surg Pediatr Card Surg Annu 2016;19:59-62.

49. Wang A, Ganapathi AM, Wang A, et al. The Modified Ross Procedure with Prosthetic Graft Wrap Does Not Prevent Autograft Failure. J Heart Valve Dis
2017;26:735-7.

50. Bouhout I, Ghoneim A, Tousch M, et al. Impact of a tailored surgical approach on autograft root dimensions in patients undergoing the Ross procedure for aortic regurgitation. Eur J Cardiothorac Surg 2019;56:959-67.

51. Oeser C, Uyanik-Uenal K, Kocher A, et al. Long-term performance of pulmonary homografts after the Ross procedure: experience up to 25 years. Eur J Cardiothorac Surg 2019;5 5:876-84.

52. Chauvette V, Bouhout I, Lefebvre L, et al. The Ross procedure is a safe and durable option in adults with infective endocarditis: a multicentre study. Eur J Cardiothorac Surg 2020;58:537-43.

53. De Paulis R, Salica A. Surgical anatomy of the aortic valve and root-implications for valve repair. Ann Cardiothorac Surg 2019;8:313-21.

54. Um KJ, Mcclure GR, Belley-Cote EP, et al. Hemodynamic outcomes of the Ross procedure versus other aortic valve replacement: a systematic review and meta-analysis. J Cardiovasc Surg (Torino) 2018;59:462-70.

55. Laforest I, Dumesnil JG, Briand M, et al. Hemodynamic performance at rest and during exercise after aortic valve replacement: comparison of pulmonary autografts versus aortic homografts. Circulation 2002;106:I57-62 .

56. Rabkin-Aikawa E, Aikawa M, Farber M, et al. Clinical pulmonary autograft valves: pathologic evidence of adaptive remodeling in the aortic site. J Thorac Cardiovasc Surg 2004;128:552-61.

57. Torii R, El-Hamamsy I, Donya M, et al. Integrated morphologic and functional assessment of the aortic root after different tissue valve root replacement procedures. J Thorac Cardiovasc Surg 2012;143:1422-8.

58. Pibarot P, Dumesnil JG, Briand M, et al. Hemodynamic performance during maximum exercise in adult patients with the ross operation and comparison with normal controls and patients with aortic bioprostheses. Am J Cardiol 2000;86:982-8.

59. Sievers HH, Schmidtke C, Graf B. Hemodynamics of semilunar valves at rest and exercise at an average of more than two years after the Ross procedure. J Heart Valve Dis 2001;10:166-9; discussion 169-70.

60. Duebener LF, Stierle U, Erasmi A, et al. Ross procedure and left ventricular mass regression. Circulation 2005;112:I415-22.

61. Chan V, Rubens F, Boodhwani M, et al. Determinants of persistent or recurrent congestive heart failure after contemporary surgical aortic valve replacement. J Heart Valve Dis 2014;23:665-70. 
62. Nötzold A, Hüppe M, Schmidtke C, et al. Quality of life in aortic valve replacement: pulmonary autografts versus mechanical prostheses. J Am Coll Cardiol 2001;37:1963-6.

63. Zacek P, Holubec T, Vobornik M, et al. Quality of life after aortic valve repair is similar to Ross patients and superior to mechanical valve replacement: a cross-sectional study. BMC Cardiovasc Disord 2016;16:63.

64. Aicher D, Holz A, Feldner S, et al. Quality of life after aortic valve surgery: replacement versus reconstruction. J Thorac Cardiovasc Surg 2011;142:e19-24.

65. McLintock C. Anticoagulant therapy in pregnant women with mechanical prosthetic heart valves: no easy option. Thromb Res 2011;127 Suppl 3:S56-60.

66. David TE, Woo A, Armstrong S, et al. When is the Ross operation a good option to treat aortic valve disease? J Thorac Cardiovasc Surg 2010;139:68-73; discussion 73-5.

67. Lansac E, Di Centa I, Sleilaty G, et al. Long-term results of external aortic ring annuloplasty for aortic valve repair. Eur J Cardiothorac Surg 2016;50:350-60.

68. Youssefi P, El-Hamamsy I, Lansac E. Rationale for aortic annuloplasty to standardise aortic valve repair. Ann Cardiothorac Surg 2019;8:322-30.

69. Basmadjian L, Basmadjian AJ, Stevens LM, et al. Early results of extra-aortic annuloplasty ring implantation on aortic annular dimensions. J Thorac Cardiovasc Surg 2016;151:1280-1285.e1.

70. Ouzounian M, Mazine A, David TE. The Ross procedure is the best operation to treat aortic stenosis in young and middle-aged adults. J Thorac Cardiovasc Surg 2017;154:778-82.

71. Bouhout I, Poirier N, Mazine A, et al. Cardiac, obstetric, and fetal outcomes during pregnancy after biological

Cite this article as: Hage A, Hage F, Valdis M, Guo L, Chu MWA. The Ross procedure is the optimal solution for young adults with unrepairable aortic valve disease. Ann Cardiothorac Surg 2021;10(4):454-462. doi: 10.21037/acs-2021rp-26 or mechanical aortic valve replacement. Can J Cardiol 2014;30:801-7.

72. Elkayam U, Bitar F. Valvular heart disease and pregnancy: part II: prosthetic valves. J Am Coll Cardiol 2005;46:403-10.

73. Pieper PG, Balci A, Van Dijk AP. Pregnancy in women with prosthetic heart valves. Neth Heart J 2008;16:406-11.

74. Mazine A, El-Hamamsy I, Ouzounian M. The Ross procedure in adults: which patients, which disease? Curr Opin Cardiol 2017;32:663-71.

75. Mazine A, Ghoneim A, El-Hamamsy I. The Ross Procedure: How I Teach It. Ann Thorac Surg 2018;105:1294-8.

76. Al Rashidi F, Bhat M, Höglund P, et al. The modified Ross operation using a Dacron prosthetic vascular jacket does prevent pulmonary autograft dilatation at 4.5-year followup. Eur J Cardiothorac Surg 2010;37:928-33.

77. Carr-White GS, Afoke A, Birks EJ, et al. Aortic root characteristics of human pulmonary autografts. Circulation 2000;102:III15-21.

78. Nishimura RA, Otto CM, Bonow RO, et al. 2017 AHA/ ACC Focused Update of the 2014 AHA/ACC Guideline for the Management of Patients With Valvular Heart Disease: A Report of the American College of Cardiology/ American Heart Association Task Force on Clinical Practice Guidelines. Circulation 2017;135:e1159-95.

79. Baumgartner H, Falk V, Bax JJ, et al. 2017 ESC/EACTS Guidelines for the management of valvular heart disease. Eur Heart J 2017;38:2739-91.

80. Misfeld M, Borger MA. The Ross procedure: Time to reevaluate the guidelines. J Thorac Cardiovasc Surg 2019;157:211-2. 